\author{
Krzysztof ZAŁECSKI ${ }^{1}$ \\ Zdzisław ŚLIWA ${ }^{2}$
}

\title{
HYBRID WARFARE AS A STRATEGIC TOOL FOR SHAPING POLICY OF THE RUSSIAN FEDERATION
}

The security policy of the Russian Federation has long created threats and imposed its will on Russia's neighbors and other nations. In recent times, Russia uses the concepts of hybrid warfare to move conflicts and crises to neighboring countries without political consequences or an outright violation of international law. The use of hybrid war methods in relation to Ukraine proved to be partially effective and showed Russia's will and capabilities to run such operations. These tactics circumvent possible engagement of the NATO and European Union (EU) members in enforcing international consequences and implementation of Article $\mathrm{V}$ of the Washington Treaty. The aim of the article is to analyze the hybrid warfare concept employed by Russia, its methods and impact on NATO and United States policy in all political aspects of the modern world. Moreover, the present article aims to present the perception of that concept by western nations. Study methods include a critical analysis and synthesis of reliable sources within the research. This study supports a deeper understanding of the complexity of the hybrid warfare model, and allows for the reader to draw practical conclusions on how to combat hybrid warfare by a single nation and multinational organizations.

Keywords: international security, Russian Federation, hybrid warfare, new generation warfare.

\section{INTRODUCTION}

The issue of "hybrid warfare" has been a broadly discussed in relation to bloodless annexation of Crimea and ongoing war in Ukraine. It has trapped academic and military theoreticians into that broadly discussed topic within articles and during academic discussions. The popularity has been growing and according to Michael Kofman just "in two short years, the word has mutated from describing how Moscow was fighting its war in Ukraine to incorporating all the various elements of Russian influence and national power" therefore it has become "the Frankenstein of the field of Russia military analysis; it

${ }^{1}$ Krzysztof Załęski, Maj. Gen. (res.), DSc, PhD, Eng, Associate Prof., Department of Applied Sciences, WSB University, Dąbrowa Górnicza, ul. Cieplaka 1c, 41-300 Dąbrowa Górnicza, Poland; e-mail: kzaleski@wsb.edu.pl. ORCID: 0000-0002-0245-5987 (corresponding author).

${ }^{2}$ Zdzisław Śliwa, DSc Phd, Col (ret.), Baltic Defence College, 12 Riia St., Tartu, Estonia; e-mail: zdzislaw.sliwa@baltdefcol.org. ORCID: ORCID: 0000-0002-5653-2941. 
has taken on a life of its own and there is no obvious way to contain it" (Kofman, 2017). It was often used in the context of ongoing modernization of the Russian armed forces to claim that it is part of building capabilities. It was to visualize that the Kremlin approach is not specifically about developing 'muscles' only by buying more equipment but it was also about using other than military 'soft' tools to challenge the West. It was supporting by energy security related challenges, accusation about supporting European radical and conservative parties, playing with oil and gas and other political and economic measures taken. However, it was also to present that Russian military thought is continuing development and it is no longer Second World War and Cold War type concept aiming to use conventional power exploiting tenets of mass and concentration of forces. The last decades have been recognized as a demonstration that the country is ready to use all available conventional and nonconventional tools in well-coordinated and sequenced way to achieve desired end state. It required an answer from the West nations to face comprehensive and coordinated threats and challenges adjusting own structures and capabilities. The paper is covering a theoretical background of the term recognizing its origins and interpretations. Specifically the Russian theoretical framework was mentioned in the context of perception of threat to the country. Its influence on theory and practical implementation by NATO countries was also covered. It is followed by considering its conventional aspect in the context of current Russian activities about new ways of conducting warfare.

\section{HYBRID WAR' AS MODERN SECURITY CONCERN}

In general it is recognized that the 'hybrid warfare' concept is not new as historically nations were using variety of tools to achieve desired aims by challenging an opponent using available options. Frank Hoffman is discussing hybrid warfare in the Joint Forces Quarterly and he is introducing historical case studies of wars between Sparta and Athens. $\mathrm{He}$ is recognizing that wars have always been more complex than just struggle between armed forces, but the new hybrid wars are different in nature. It is allowing him to recognize that "hybrid threats incorporate a full range of modes of warfare, including conventional capabilities, irregular tactics and formations, terrorist acts that include indiscriminate violence and coercion, and criminal disorder. These multi-modal activities can be conducted by separate units, or even by the same unit, but are generally operationally and tactically directed and coordinated within the main battle space to achieve synergistic effects in the physical and psychological dimensions of conflict" (Hoffman, 2009).

Hoffman is strongly highlighting that hybridity is not only linked with non-state actors. For him, what is very dangerous and challenging, is utilization of that type of warfare by state actors is making any conflict very damaging as military conflict could be preceded by non-military actions, which could be destructive for any state by attacking all its vital functions. Current security challenges, as posed by non-military actors in the South Europe, are presenting it very clearly. Those are using any opportunity offered by democratic nations to challenge them exploiting their way of life. It is requiring all governmental and military organizations to be more adaptive and it requires complex, Whole-of-Government Approaches toward security as "the political, security, economic and social spheres are interdependent: failure in one risks failure in all others" (Whole of Government Approaches...). It is linked with experiences coming from regimes changes in the Middle East when the dictators were not ready and able to survive public disappointment. The 
situation there had been shaped through years leading to establishing building disappointment, recognition of inequality and creation of local powers capable to face dictatorships. Such an initial indirect and non-kinetic local forces' approach had transferred into uprisings and civil wars, which with external support have changed the whole security situation there allowing. Nevertheless, as side effect, it has allowed emergence of many radical movements' as those have found a 'window of opportunity' to aggressively forward their dangerous ideas.

The consequences still have been visible as of fragile situation in the whole region with global implications. North Africa is a hot spot full of radical movements, rebels, religious groups and fractions fighting for power causing huge movement of refugees to Europe. Among them, there are also radicals being ready to start their 'hybrid warfare' on European ground; the war, which is already on going. The lessons learned were drawn by Russian political and military leadership based on assumption that Western countries are using many non-military methods to change regimes and political situation in targeted countries. It was supposed to be aimed to create preconditions to build internal opposition. It was linked with using local forces by sponsoring them to begin unrest and later to change government or to overthrow dictators with support from outside by funding, arming of delivering missed capabilities e.g. air power, precise strikes, intelligence, training etc. It was partially true in the case for example Libya but it was specific area of operations and specific internal situation in that region. That approach was not to be implemented in any scenario and against any country. Even in Ukraine so called 'hybrid' approach was not fully working, as there was a requirement to deploy Russian armed forces for direct combat and by utilizing artillery support, intelligence to preserved gains achieved by local volunteers, paramilitary units, and mercenaries. The open borders were supporting transit of weapon and units to continue the war.

The term 'hybrid warfare' is broad and it has many components as it includes parallel and coordinated use of conventional and unconventional ways and assets to achieve desired political - military end state. It was raised by William Nemeth from the Naval Postgraduate School in the thesis titled "Future war and Chechnya: a case for hybrid warfare" who recognized that "hybrid societies are a mixture of the modern and the traditional. Hybrid societies in turn have organized hybrid military forces, and it is these forces that will challenge military and diplomatic planners in the future" (Nemeth, 2002). He recognized Chechen war as 'hybrid' covering Chechen society and forces claiming "operationally, hybrid military forces are superior to western forces within their limited operational spectrum. Their main strength lies in the hybrid's ability to employ modern technology against its enemies as well as its ability to operate outside the conventions governing war, which continually restrains its modern foe" (Nemeth, 2002).

It was recognized that such the type of warfare it conducted rather by no-state actors than national ones. That term has however started to be more popular after Russian Chief of General Staff General Valery Gerasimov published his paper (Герасимов, 2013; Thomas, 2016) as it was recognized that state actor achieved desired end state using skilful combination of 'soft' and 'hard' power with the focus on the former. It was allowing denying of applying the term 'war'. 


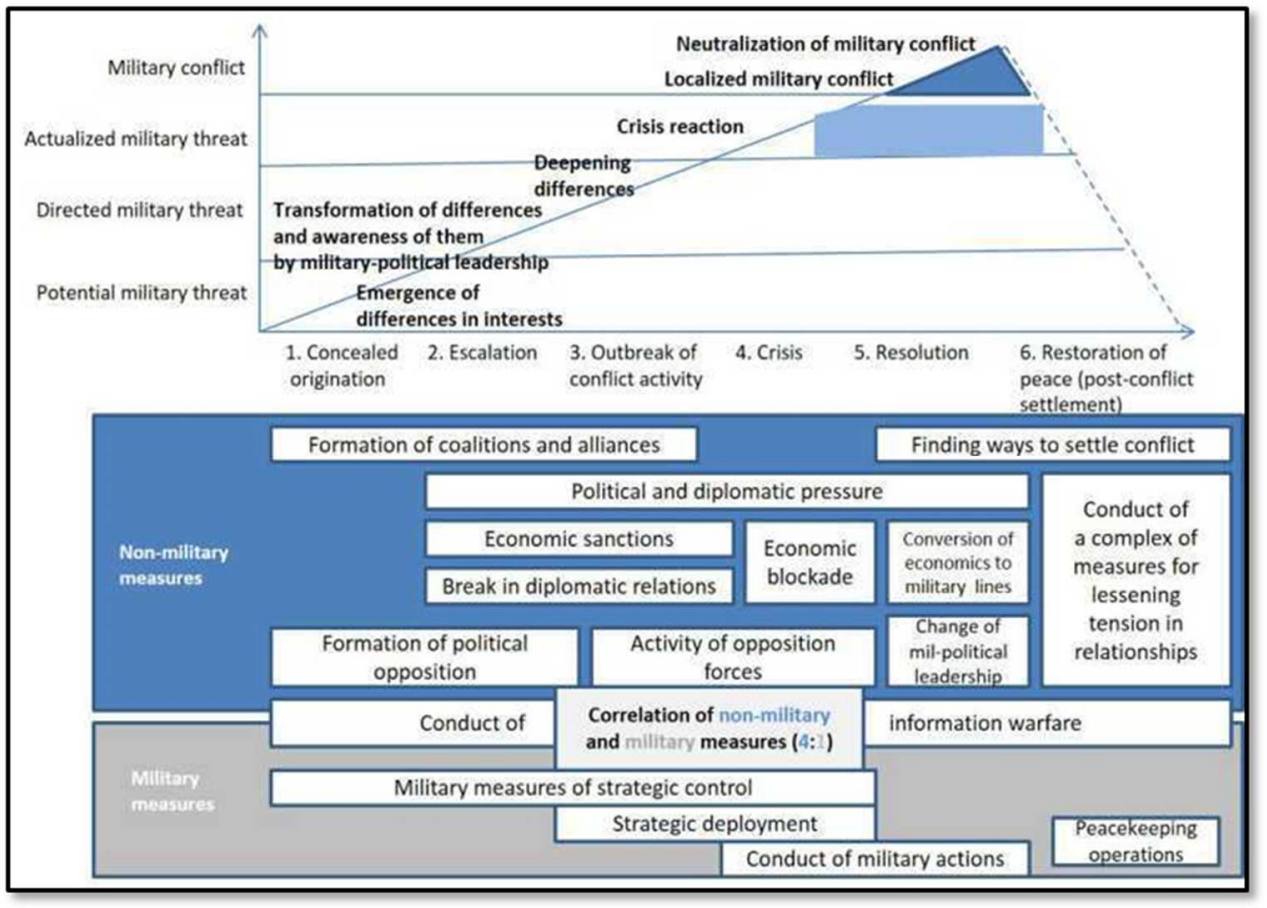

Fig. 1. The Role of Non-Military Methods in the Resolution of Interstate Conflicts

Source: (Harding, 2016).

What is notable, in that interesting paper Gerasimov is not discussing the term of 'hybrid warfare' at all and he is rather discussing the changes in new reality of 'nonlinear' warfare recognizing that "the role of non-military ways in reaching political and military goals has raised, which in some cases significantly exceeded the power of armed forces" (Герасимов, 2013). The outcome of that thinking is presenting utilization of both conventional and nonconventional means in a sequence of follow-on phases of an operation. It is related to his perception of threats, which are being faced by Russia as expressed during a speech in the Academy of Military Sciences. He said "Russia faces a broad range of multi-vector threats, especially linked to the use of soft power: political, diplomatic, economic, informational, cybernetic, psychological and other non-military means" as the result "the main result of Russian military science should be practical, leading the way in formulating new ideas and thinking on these issues" (Roger McDermott, 2016b). His approach as of the famous article in 2013 has been also called 'Gerasimov doctrine', in which the role of non-military measures is very strongly expressed within all the phases as presented on fig. 1.

Military capabilities are used from phase IV Crisis after strategic deterrence and deployment supplemented by constant information operations. Phases I to III are based on implementation of other than military tools. As Russia in suffering as of economic sanctions, it is considered by Kremlin to be under attack by Western powers using economic tolls supported by political pressure and war in information, cyber and other domains. External support for opposition and building broader coalitions including extension of 
NATO and EU are also treated as directed against Russia. Therefore, Gerasimov was rather discussing the 'new generation warfare' as a type of warfare directed against Russia by external powers including an intent to initiate 'colour revolution' to change the government and weaken the country. Russian military thinkers examined lessons learned from Iraq, Libya and wars in Chechnya and Georgia to initiate 'hybrid' type warfare in Ukraine surprising the West. It has been used to underpin political objectives to restore the nation's role as global player, to restore influence within 'near border' and in the long term to ensure better position in the context of ongoing changes in the security landscape of Asia.

Roger McDermott recognizes "the non-existence of a Russian hybrid doctrine, or approach to warfare per se. Rather, according to his public remarks, Gerasimov sees the need to respond to the United States and the North Atlantic Treaty Organization (NATO), which he claims are forming such capabilities" (McDermott, 2016). Likewise, Nicu Popescu states "the term itself is a Western description of Russian military practice, rather than a conceptual innovation originating in Russia" and "the West is carrying out its own hybrid operation against Russia in the shape of smear campaigns and the imposition of economic and financial sanctions" (Popescu, 2015). Similarly, Kofman is claiming that the term has strongly overwhelmed mind in the West being part of many conferences talking about the same using variety of approaches (Кофман, 2016). Therefore, Gerasimov was talking "about how the West shapes the battlefield prior to intervention, not suggesting that Russia must do the same" (Kofman, 2017). He recognized what tools and ways could be used against Russian in the current and future political environment by the West nations to challenge the country. The team Sergey Shoygu and General Gerasimov was to move armed forces modernization forward as decided and approved by President and implementation was speeded up. The symbol of the whole government approach was the National Defense Control Centre (NDCC) ${ }^{3}$ merging all national bodies involved in defence in one command and control centre. Gerasimov had also very personal reasons to publish such the paper, as he "was keen to establish himself as a reforming general supportive of the new Defense Minister Sergei Shoygu who was eager to continue such efforts albeit in modified form. Consequently, he chose to return to the theme of Russian views of future warfare" (McDermott, 2016b).

It was also based by broad historical and military knowledge of the General and his experiences when commanding troops.

Kofman is linking complex approach with George F, Kennan memo on political warfare as "the employment of all the means at a nation's command, short of war, to achieve its national objectives. (...) They range from such overt actions as political alliances, economic measures, and 'white' propaganda to such covert operations as support of 'friendly' foreign elements, 'black' psychological warfare and even encouragement of underground resistance in hostile states" (The memo: Kennan, 1948). The developments in Russian 'near border', changes of regimes in Middle East, caused Anthony Cordesman linked the new perception of warfare with fact that "Russian military officers now tied the term 'Colour Revolution' to the crisis in Ukraine and to what they saw as a new US and European approach to warfare that focuses on creating destabilizing revolutions in other states as a means of serving their security interests at low cost and with minimal casualties" (Cordesman, 2014). Those attempts to initiate a revolution are set of overt and covert operations united by clearly defined end state and supported by proper funding and qualified manning not forgetting

${ }^{3}$ NDCC - also known as National Defense Management Center. 
about strategic patience as it takes time to achieve what is expected. The attempts to be ready to face such the threat was highlighted by Gerasimov who "has called on leading military theorists and specialists as well as the defines industry and the government to jointly develop a 'soft power' strategy to counter the potential threat from 'colour revolutions"' (McDermott, 2016a). He mentioned the need to develop variety of both soft tools supported by hard conventional power as represented by armed forces (external threat) and National Guard (internal threat). The later one is based on assumption that "'coup' in the colour revolution model is regarded by Moscow as a form of hybrid warfare conducted by foreign powers against Russia's interests" (McDermott, 2016a). Such the ideas were supported by Russian leading military theory, Army-General Makhmut Gareev, the president of the Academy of Military Sciences.

\section{THE WEST PERCEPTION OF THE CONCEPT}

The complexity of 'Hybrid Warfare' has been recognized by NATO in the report Multiple Futures Project. Navigating Towards 2030 released by the Allied Command Transformation to "identify potential roles within the military realm that NATO could consider emphasizing for 2030" and among them the need to adapt "to the Demands of Hybrid Threats" (Multiple Futures Project, 2009). Such the type of warfare adopted by NATO's adversaries is "both interconnected and unpredictable, combining traditional warfare with irregular warfare, terrorism, and organised crime. Psychologically, adversaries will use the instantaneous connectivity of an increasingly effective mass media to reshape or summarily reject the liberal values, ideas, and free markets that characterise the Alliance" (Multiple Futures Project, 2009).

As an effect, an enemy will use all opportunities within engagement space to influence the NATO nations' economy, politics to weaken their unity, to harm societies, to shape information domain exploiting unconditionally all recognized vulnerabilities. In the case of adversaries represented by nations the variety of possible tools is incredibly vast. In general "risks and threats to the Alliance's territories, populations and forces will be hybrid in nature: an interconnected, unpredictable mix of traditional warfare, irregular warfare, terrorism and organised crime" (Multiple Futures Project, 2009). What is noticeable the document is not mentioning Russia at all even though the document was published after Russian - Georgian war in 2008. However, recommendations are highlighting the necessity to "develop a culture where leaders and capabilities are well suited for irregular warfare or the hybrid threat, while simultaneously maintaining NATO's conventional and nuclear competency" (Multiple Futures Project, 2009) and not so many nations possess strong enough power to challenge NATO nations. One of dangers of such the risks is that the NATO Article V could not be implemented as of the questionable nature of such the threats. It is also important to mention that the nature of hybridity is causing the need to integrate European nations much closer as military threat is not the major one.

All the prerequisites of an aggression could be non-military in nature asking all European actors to cooperate closely; cooperation with European Union will be one of key facilitators to face weaknesses and threats next to closer internal consolidation of each single Alliance nation. The 'hybrid warfare' was matter of discussion during NATO Summit in Wales to

"address the specific challenges posed by hybrid warfare threats, where a wide range of overt and covert military, paramilitary, and civilian measures are 
employed in a highly integrated design. It is essential that the Alliance possesses the necessary tools and procedures required to deter and respond effectively to hybrid warfare threats, and the capabilities to reinforce national forces. This will also include enhancing strategic communications, developing exercise scenarios in light of hybrid threats, and strengthening coordination between NATO and other organisations, in line with relevant decisions taken, with a view to improving information sharing, political consultations, and staff-to-staff coordination. We welcome the establishment of the NATO-accredited Strategic Communications Centre of Excellence in Latvia as a meaningful contribution to NATO's efforts in this area. We have tasked the work on hybrid warfare to be reviewed alongside the implementation of the Readiness Action Plan" (Wales summit declaration..., 2014).

The document widely discussed Russian annexation of Crimea and support for separatists in the West Ukraine.

The hybrid warfare is highlighted in US Joint Operating Environment JOE 2035 as

"a number of revisionist states will employ a range of coercive activities to advance their national interests through combinations of direct and indirect approaches designed to slow, misdirect, and blunt successful responses by targeted states. These hybrid stratagems will be designed to spread confusion and chaos while simultaneously avoiding attribution and potentially retribution" (Joint Operating Environment, 2016).

Russia in mentioned as a country, which is trying to forward national regional interests along with an attempt to go back to global scene as great power. The document is also highlighting that US armed forces' advantage in conventional war domain caused potential adversaries to look for other than military tools by "development of asymmetric, unconventional, irregular, and hybrid approaches" (Joint Operating Environment, 2016). The threats are treated in broader spectrum, also geographically, as US is involved directly in many regions and each of them is possessing unique characteristics. Adaptation based on throughout analysis of specific dimensions of them separately is one of challenging tasks to ensure that particular centre of gravity of a respective 'hybrid war' is properly recognized and engaged decisively.

NATO's Annual Report 2015 is defining the hybrid challenges by "combining military and non-military means of inflicting damage or creating instability" (The Secretary General's Annual Report, 2016) and it was recognized as not new phenomenon. However, the scale, speed and intensity are requiring new ways to prepare to face, to deter and finally to defend against such the evolving threats. It requires consolidation of all available resources to ensure that "a wide range of overt and covert military, paramilitary, and civilian measures are used to disrupt, confuse, damage or coerce - Allies agreed to develop a strategy on NATO's role in countering hybrid warfare" (The Secretary General's Annual Report, 2016). In the case of NATO, a consolidated strategy is of critical importance based on consensus of all member nations as it is allowing developing proper tools to face threat. The term 'smart defence' is one of facilitators to develop those asking nations to complement capabilities in harmonized way. The report is highlighting the importance of non-military assets preparedness as military sector is heavily relying on civilian assets in 
transportation, manpower, satellite communication and host nation support (The Secretary General's Annual Report, 2016). It is obvious that without such the readiness and support operations cannot be conducted within protracted conflict and their sustainment will not be reliable. The report is mentioning aggressive behaviour as presented by military activities next to NATO's borders and it is recognized by stating that an unpredictable country is challenging the security in Europe (The Secretary General's Annual Report, 2016). NATO is the main military arm of Euro-Atlantic community but close cooperation with European Union as strategic partner must be maintained and enhanced to utilize fully politic, economic and civilian instruments of power orchestrated with military one.

NATO Secretary General Jens Stoltenberg discussed 'hybrid warfare' as

"the dark reflection of our comprehensive approach. We use a combination of military and non-military means to stabilize countries. Others use it to destabilize them" and he admitted "hybrid warfare is nothing new. It is as old as the Trojan horse. What is different is that the scale is bigger; the speed and intensity is higher; and that it takes place right at our borders" (Keynote Speech..., 2015).

Stoltenberg highlighted that it is of great importance to understand the nature of such the threat to deter it and defend against as enemy is using variety of tools to exploit any recognized weakness. The soft tools could be just

"a prelude to a more serious attack; because behind every hybrid strategy, there are conventional forces, increasing the pressure and ready to exploit any opening. We need to demonstrate that we can and will act promptly whenever and wherever necessary" (Keynote Speech..., 2015).

When asked about the role of soft power and hard power represented by NATO the Secretary General recognized the importance of both underlining that

\begin{abstract}
"we need classical conventional forces. Hybrid is about reduced warning time. It's about deception. It's about a mixture of military and non-military means. So therefore we have to be able to react quickly and swiftly. And so when we are increasing the readiness and the preparedness of our forces, well that is also an answer to the hybrid threat. When we are doing more to increase our capacity when it comes to intelligence, surveillance, reconnaissance, then it's also an answer to hybrid threats... So to increase the capability, the readiness of our conventional forces is also part of the answer to hybrid" (Keynote Speech..., 2015).
\end{abstract}

The NATO Warsaw Summit in July 2016 in Warsaw also recognized a possibility of 'hybrid attacks' among security challenges from state and non-state actors. In that context "resilience and ability to respond quickly and effectively to cyber-attacks, including in hybrid contexts" (Warsaw Summit Communiqué, 2016) created an officially recognized an important domain of security. The 'hybrid warfare' threat was defined as where "broad, complex, and adaptive combination of conventional and non-conventional means, and overt and covert military, paramilitary, and civilian measures, are employed in a highly integrated 
design by state and non-state actors to achieve their objectives" (Warsaw Summit Communiqué, 2016). To achieve success

\begin{abstract}
"the primary responsibility to respond to hybrid threats or attacks rests with the targeted nation. NATO is prepared to assist an Ally at any stage of a hybrid campaign. The Alliance and Allies will be prepared to counter hybrid warfare as part of collective defence. The Council could decide to invoke Article 5 of the Washington Treaty. The Alliance is committed to effective cooperation and coordination with partners and relevant international organisations, in particular the EU, as agreed, in efforts to counter hybrid warfare" (Warsaw Summit Communiqué, 2016).
\end{abstract}

The challenge is however how to define the border between conventional attack and 'hybrid' allowing full implementation of Article V based on consensus of all the nations. It is connected with the risk of leaving targeted countries alone during critical period of an attempt to seize those using "little green men". The Warsaw Summit recognized the need to cooperate closely with European Union as strategic partner based on the complexity of threats and lack within NATO proper tolls to face those being non-military in nature.

In general, the definitions and perceptions of 'hybridity' are differing but in essence, the nature is the same based on the need to utilize all possible tolls, which are suitable to successfully engage an opponent. The utilization of all available tools is linked with type of political system as decision-making and freedom to use military and non-military means is easier in the case of authoritarian systems; of course if those are ready and aware about threat. It is giving an advantage over democratic nations as non-military options could be exploited based on single authority or ruling elites' decision in protracted way not taking into consideration people's opinion. Armed forces and law enforcement troops could be employed even faster leaving an opponent no reaction time to face the threat.

\title{
4. THE IMPLEMENTATION OF THE CONCEPT BY RUSSIA
}

Moscow is using 'hybrid' approach very skilfully focusing on comprehensive use of political and military domains supported by constant uncertainty regarding military intentions and developments. It partially achieved desired outcome by destabilizing security in the region, by questioning NATO and European Union enlargement to the East and challenging NATO by exposing its weaknesses and limited capabilities. Nevertheless, what is noticeable, still nuclear capabilities are one of major deterrence factors. The ongoing continuity of exercises and large-scale mobilizations, as it happened at the end of August 2016, are keeping NATO in uncertainty about the real aims of Russia. This unexpected verification of armed forces readiness (Внезапная проверка..., 2016) was a demonstration toward the outcome of the Warsaw Summit and NATO's decision to deploy battalion size units to the East Europe. Such initiatives of the Summit as: The United States' European Reassurance Initiative, the Transatlantic Capability Enhancement and Training Initiative, UK-France Combined Joint Expeditionary Force concept (Warsaw Summit Communiqué, 2016) or the Visegrad Group decision to provide rotational presence and to conduct exercises in Baltic States in 2017 are important. The issue is always linked with the size and readiness to use all the units in time to face aggression especially an unexpected one. Nevertheless, NATO Secretary General did not exclude dialogue next to extended deterrence (Opinion piece by NATO, 2016). So forward presence should be linked with 
dialogue and showing the force. The nations are understanding role of conventional power and such the lack of power is recognized as weakness worth to be exploited after softening enemy denying use of full capabilities in limited timeframe.

The scale of snap check exercises was to prove that deployment of multinational battalions is rather minor combat power compared to Kremlin's readiness to mobilize not only military but also non-military capacities in short time to conduct large scale operations to achieve desired end state. An exemplification were manoeuvres in August 2016 with units from three military districts (Central, Western, Southern MDs), Northern Fleet, Aerospace Forces and Airborne Troops. It was also precondition for the Strategic level command-staff exercise of the Southern Military District codenamed "Caucasus 2016" with some 12500 troops supported by aviation and heavy equipment. It was followed in October 2016 by large-scale exercise of Russian civil defence involving some $40 \mathrm{mln}$ people nationwide. The exercise "Zapad 2017" was a show and continuity of large-scale manoeuvres with nuclear scenarios as during "Zapad 2009" and "Vostok 2010" exercises to threaten nations, which deployed troops to Baltic region. That comprehensive approach to operations involving all the national assets is supported by NDCC.

Russia is continuing modernization of armed forces toward modern battlefield and it must be treated very seriously as the huge effort was done presenting new capabilities and readiness to act decisively in the limited timeframe based. It is supported by very short chain of command and decision-making cycle allowing well-coordinated utilization of all available national assets. To facilitate it the NDCC has the same manning and structure in peace and war time. It is able to utilize all national non-military and military capabilities at 5:1 (4:1) ratio within joint effort to facilitate joint multi-institutional comprehensive approach and "if implemented as planned - should greatly improve Russia's speed of reaction and information exchange, assisting in honing its coordinated capabilities for hostile action still further" (Giles, 2016). The change of the command and control system was redefined by creation of four military districts and adjustment of force structure. Initial focus on creation of independent and more powerful brigades subordinated to military districts was revised as exemplified by recreation of $1^{\text {st }}$ Guards Tank Army in the West Military District, reorganization of the $20^{\text {th }}$ Army and decision to create three new divisions based on existing combat, combat support and combat service support units (Carik, 2016). The creation of the National Guard in April 2016 is to support that trend allowing using other than military assets to cover security of critical political, military and economic infrastructure and to enhance readiness to contribute to territorial defines in a case of any attempt to endanger the territorial integrity of the Russian Federation.

The theory of the 'hybrid warfare' is practiced aboard by Russian military and military assets to gain more experiences how to deal with any threat coming from inside and outside of the country as it is linked with terrorist organizations inside Russia and also threat of internal 'colour revolution'. It is practiced in Syria using combat units and also private military companies (PMC). The latter are still not legal in Russia but they are recruiting its citizens and they also have Russian leadership. According to the Foreign Policy already in 2013 Russian mercenaries from the "Slavonic Corps" were fighting Islamic State in Syria. In addition, its successor, PMC 'Wagner' "has been fighting major battles in both Ukraine and Syria - including battles of Palmyra” (Miller, 2016; Они сражались..., 2016; Sparks, 2016; Galeotti, 2016). 


\section{CONCLUSION}

Sun Tzu has recognized that "Hence to fight and conquer in all your battles is not supreme excellence; supreme excellence consists in breaking the enemy's resistance without fighting" (Sun Tzu, Translated by Lionel Giles, Part III) and this also part of current strategic thinking in Russia. The old type thinking related to Cold War period is over and there are no longer capabilities to conduct such large-scale operations to conquer vast territories. The definition of Frank Hoffman recognizing current warfare as "a tailored mix of conventional weapons, irregular tactics, terrorism, and criminal behaviour in the same time and battlespace to obtain [a group's] political objectives" (Kofman, 2016) is up to date. It is understood and implemented by leadership so opponents as NATO and EU are challenged other than military ways to weaken them, to destroy their internal cohesion, to deepen internal divisions. The challenge is however, that perception of that approach to warfare is differently understood among nations. It has direct consequences in investing in armed forces development and not fully implementing the concept of the whole government approach. It could be visible by variety of political parties' perception of threats, different priorities in economic development lacking unification e.g. within energy security and deals related to transfer of gas and oil.

Currently tools allowing influencing adversaries and advancing and global market and economy are supporting evolution of warfare by adding, much stronger than in the past, variety of options to be exploited. Combination of continuous build-up of armed forces, National Guard along with private security and military companies is ensuring that there is no threat for Russia to be attacked from outside. It is also ensuring close control of internal situation to keep opposition under control, to manage terrorist threat and to face any 'colour revolution' attempt inspired by external powers. It is partially linked with recognition of power of popular movements which are capable to change any government and historically Russian citizens were able to change the whole political system effectively. Parallel, development of military and law enforcement capabilities is a facilitator of using other instruments of power supported by skilfully utilizing information and cyber domains. The 'hybrid' approach is visualized and explained in 'Gerasimov doctrine' and capabilities are available. The challenge is how long those could be preserved as of economic reasons. In short term until 2020-2022 it is doable but in long term the situation must be improved to avoid implosion of the current system.

The answer from the West nations must be decisive and it must include all possible tools to pressure Russia constantly. It must be conducted in much consolidated way in harmonized effort of all members of European and Euro-Atlantic communities as any signal of lack of cohesion or hesitation will be exploited against them. The 'hybrid' threat is requiring comprehensive answer to face them by consolidating all available resources within each single nation and also within security organizations. To face them NATO agreed ,,a hybrid strategy to cope with the fast-moving challenges posed through a range of military and non-military means" (The Secretary General's Annual Report, 2016). However, it is necessary to remember that complexity of challenges must be faced by complex and coordinated approach related not only to deny propaganda, information campaigns, cyber-attacks and other soft non-military options to deny the West nations ability to react and to undermine their cohesion. It that domain Russia is already successful, as "concerted effort to establish networks of political influence has reached into Europe's core. Be they Putinverstehern, useful idiots, agents of influence, or Trojan Horses, the aim 
is the same: to cultivate a network of organizations and individuals that support Russian economic and geopolitical interests, denounce the EU and European integration, propagate a narrative of Western decline, and vote against EU policies on Russia (most notably sanctions) - thus legitimating the Kremlin's military interventionism in Ukraine and Syria, weakening transatlantic institutions, and undermining liberal democratic values" (Polyakova, 2016).

The report is linked with an effort to undermine nations which are the most powerful European power influencing all the domains of existing status in all the domains of modern societies. To deny further influence "European policy makers can and should take common action to expose, limit, and counter Russia's attempt to use economic leverage and seemingly benign civil society activities to manipulate policy and discourse in open societies" (Polyakova, 2016). The report is advising three sets of actions for France, Germany and the UK as follow: to expose Russia's network of Trojan horses by shining a light on opaque connections, to limit Russia's influence through government actions and to reinvest in European values and democratic institution. Next to non-military means the conventional capabilities must be preserved and develop further as military weakness could be exploited by further territorial requirements recognizing that Europe is focused only on minor actions as deployment of limited forces to the East Europe believing that it is enough to deter. The scale of Russian 'snap exercises', nuclear scenarios and continuous modernization of armed forces are something to be taken very seriously investing in capabilities to face an unexpected attempt to further change national borders. Solid analysis must be done as there is a risk that "the actual future capability will surely differ from whatever it is that NATO and the EU are currently planning to counter" (McDermott, 2016 b) causing a danger of being not prepared to face opponent on the future battlefield. The problems caused to Russian economy by economic sanctions are working although slowly but in long term they will affect the country asking for decisions. The danger is that decisions could be linked with aggressive behaviour and that is requiring being ready for the worst-case scenario within 'new generation warfare' options.

\section{REFERENCES}

Cordesman, A. (2014). Russia and the 'Color Revolution. Center for Strategic and International Studies, May 28. Access on the internet: https://www.csis.org/analysis/russia-and-\%E2\%80\% 9Ccolor-revolution\%E2\%80\%9D.

Galeotti, M. (2016). Moscow's Mercenaries in Syria. "War on the Rocks”, April 05. Access on the internet: http://warontherocks.com/2016/04/moscows-mercenaries-in-syria/.

George F. Kennan on Organizing Political Warfare, April 30, 1948, History and Public Policy Program Digital Archive, Wilson Centre. Access on the internet: http://digitalarchive. wilsoncenter.org/document/114320.pdf?v=941dc9ee5c6e51333ea9ebbbc9104e8c.

Giles, K. (2016). Russia's 'New' Tools for Confronting the West Continuity and Innovation in Moscow's Exercise of Power. London: The Royal Institute of International Affairs Chatham House, March.

Harding, J. (2016). Russia's Perception Warfare - The development of Gerasimov doctrine in Estonia and Georgia and its application in Ukraine. "Wordpress.com", June 22. Access on the internet: https://toinformistoinfluence.com/2016/06/22/russias-perception-warfare-the-development-of-gerasimovs-doctrine-in-estonia-and-georgia-and-its-application-in-ukraine/ 
Hoffman, F. (2009). Hybrid Warfare and Challenges. "The Joint Forces Quarterly" issue 52, National Defense University Press, Washington 1st quarter 2009.

Joint Operating Environment JOE 2035. Washington: Joint Force Development J7, July 14, 2016.

Keynote Speech by NATO Secretary General Jens Stoltenberg at the opening of the NATO Transformation Seminar I. Access on the internet: NATO Website, May 19, 2015, http://www.nato.int/cps/en/natohq/opinions_118435.htm.

Kofman, M. (2016). Russian Hybrid Warfare and Other Dark Arts. "War on the Rocks", March 11. Access on the internet: https://warontherocks.com/2016/03/russian-hybrid-warfare-andother-dark-arts/.

McDermott, R. (2016a). Gerasimov Calls for New Strategy to Counter Color Revolution. "Eurasia Daily Monitor" Vol. 13, issue 46, March 08. Access on the internet: https:// jamestown.org/program/gerasimov-calls-for-new-strategy-to-counter-color-revolution/\#. VuFxSfkrLRY.

— (2016b). Does Russia Have a Gerasimov Doctrine?. Parameters" 46 (1), Carlisle Barracks Spring.

Miller, J. (2016). Putin's Attack Helicopters and Mercenaries Are Winning the War for Assad. The Foreign Policy March No. 30. Access on the internet: http://foreignpolicy.com/2016/ 03/30/putins-attack-helicopters-and-mercenaries-are-winning-the-war-for-assad/.

Multiple Futures Project. Navigating Towards 2030. Norfolk: Allied Command Transformation, April.

Opinion piece by NATO Secretary General Jens Stoltenberg. Access on the internet: NATO Website, July 19, 2016, http://www.nato.int/cps/en/natohq/opinions_134210.htm.

Polyakova, A. (2016). Introduction The Kremlin's Toolkit Of Influence In Europe [in:] Laruelle, M., Barnett, N., Polyakova, A., The Kremlin's Trojan Horses. Russian Influence in France, Germany, and the United Kingdom. Washington: The Atlantic Council, DINU Patriciu Eurasia Center, November, No. 3.

Popescu, N. (2015). Hybrid tactics: Russia and the West. European Union Institute for Security Studies, Alert Issue 46 October.

Sparks, J. (2016). Revealed: Russia's 'Secret Syria Mercenaries. "Sky News”, August 10. Access on the internet: http://news.sky.com/story/revealed-russias-secret-syria-mercenaries-10529248.

Sun Tzu, The Art of War. Translated by Lionel Giles. Access on the internet: http://classics. mit.edu/Tzu/artwar.html.

The Secretary General's Annual Report (2016). Brussels: NATO Public Diplomacy Division.

Thomas, T. (2016). Thinking Like A Russian Officer: Basic Factors And Contemporary Thinking On The Nature of War. The Foreign Military Studies Office (FMSO), Fort Leavenworth, April. Wales Summit Declaration Issued by the Heads of State and Government participating in the meeting of the North Atlantic Council in Wales, September 05, 2014. Access on the internet: http://www.nato.int/cps/en/natohq/official_texts_112964.htm.

Warsaw Summit Communiqué Issued by the Heads of State and Government participating in the meeting of the North Atlantic Council, Warsaw, July 8-9, 2016. Access on the internet: http://www.nato.int/cps/en/natohq/official_texts_133169.htm.

Whole of Government Approaches to Fragile States (2006). Paris: Organisation for Economic Co-Operation and Development.

William, N. (2002). Future war and Chechnya: a case for hybrid warfare. Monterey: Naval Postgraduate School, June. 
Внезапная проверка объявлена в трех военных округах, Северном флоте, ВКС и ВДВ (2016). Tass News Agency, August 25. Access on the internet: http://tass.ru/armiya-i-opk/ 3565111 .

Герасимов, В. (2013). Ценность Науки в Предвидении. Новые вызовы требуют переосмыслить формы и способы ведения боевых действий. "Военно-промышленный курьер” No 8 (476), Moscow, February 27. Access on the internet: http://www.vpk-news. $\mathrm{ru} / \mathrm{articles} / 14632$.

Кофман, М. (2016). Гибридная война, которой нет, «Ведомости» (Vedomosti), April 20. Access on the internet: http://www.vedomosti.ru/opinion/articles/2016/04/20/638380gibridnaya-voina.

Они сражались за Пальмиру (2016). “Fontanka”, March 29. Access on the internet: http://www.fontanka.ru/2016/03/28/171/.

Царик, Ю (2016). Сивицкий Арсений, Беларусь в контексте противостояния Россия HАTO. Minsk: Центр стратегических и внешнеполитических исследований, Center for Strategic and Foreign Policy Studies.

DOI: $10.7862 /$ rz.2020.hss.11

The text was submitted to the editorial office: October 2019.

The text was accepted for publication: March 2020. 